\title{
TRANSLATION COMPETENCE: JAPANESE AND ENGLISH EMOTIVE WORDS WITH THE MEANING "SURPRISE" (LINGUACULTURAL ANALYZE)
}

\author{
Fatkulina Luiza \\ Tashkent State University of Oriental Studies, Department of Japanese Philology \\ Senior Lecturer \\ ORCID: https://orcid.org/0000-0001-6531-9440
}

Article DOI: https://doi.org/10.36713/epra9172

DOI No: $10.36713 /$ epra9172

\begin{abstract}
The research article focuses on linguacultural analyzing the Emotive words with the meaning "Surprise" with natural native examples. Analyzing emotional vocabulary and learning about different ways of expressing emotions in different words can help users of different styles to better understand each other in communication. Research on emotion has expanded significantly in recent years. The results of the research can contribute to clarify exact difference and linguacultural specifications of surprising emotive words in Japanese and English. Additionally, it helps to improve translation competence on emotive words.
\end{abstract}

KEY WORDS: linguaculture, emotive words, translation competence.

\section{INTRODUCTION}

Language is used as a means of expressing one's feelings and ideas. The term "emotive communication," first used by Marty (1908), is defined as "the intentional, strategic signaling of affective information in speech and writing ...in order to influence partners' interpretations and reach different goals" (Caffiand Janney 1994:328). What emotive communication refers to is broader than expressions of what is commonly thought of as emotions such as anger and joy. It represents what is considered to reflect subjective perspectives and includes expressions of evaluative stances, moods, attitudes, degrees of emphasis, and viewpoints. It corresponds to what Lyons (1977) called "expressive meaning."

Despite the importance of the affective dimensions of language, mainstream linguistics in Western traditions has paid relatively little attention to this field of inquiry. Affect has been considered to be "too slippery an area of language for 'scientific' investigation," and has been "consistently set aside as an essentially unexplorable aspect of linguistic behavior" (Besnier 1990:420). ${ }^{1}$

But this does not mean that the investigation on emotive communication is neglected at all by the scholars in the world. Prague school of functionalism intentionally introduced the living nature of language. Pekrun $\mathrm{R}^{2}$ classifies four groups of emotions:

1) Achievement emotions;

2) Epistemic emotions;

\footnotetext{
${ }^{1}$ Satoko Suzuki. Emotive Communciation in Japanese: An Introduction [Pragmatics \& Beyond New Series, 151] 2006. x, 234 pp

${ }^{2}$ Pekrun, R. (2014). Emotions: Functions and effects on learning. In N. M. Seel(Ed.), Encyclopedia of the Sciences of Learning (pp. 1141-1146). NewYork: Springer
} 


\section{EPRA International Journal of Research and Development (IJRD) \\ - Peer Reviewed Journal}

Volume: 6 | Issue: 12 | December 2021

3) Topic emotions;

4) Social emotions.

Achievement emotions: achievement activities and result of them such as enjoyment of learning, knowing something new; pride and hope of success; worrying and shame of failure.

Epistemic emotions: cognitive problems: surprise about a new assignment, being curious about upcoming obstacles, to be irritated or confused about the challenges also being delighted when the task is resulted positively.

Topic emotions: relating topics in life. Feeling the condition of the sick person, feeling empathy with somebody's fate (in a fiction book is also possible) described in a conversation or novel and so forth.

Social emotions: related to relationships of people (peers, coworkers, relatives and etc). Emotions such as sympathy, love, compassion, admiration, envy, anger, social anxiety.

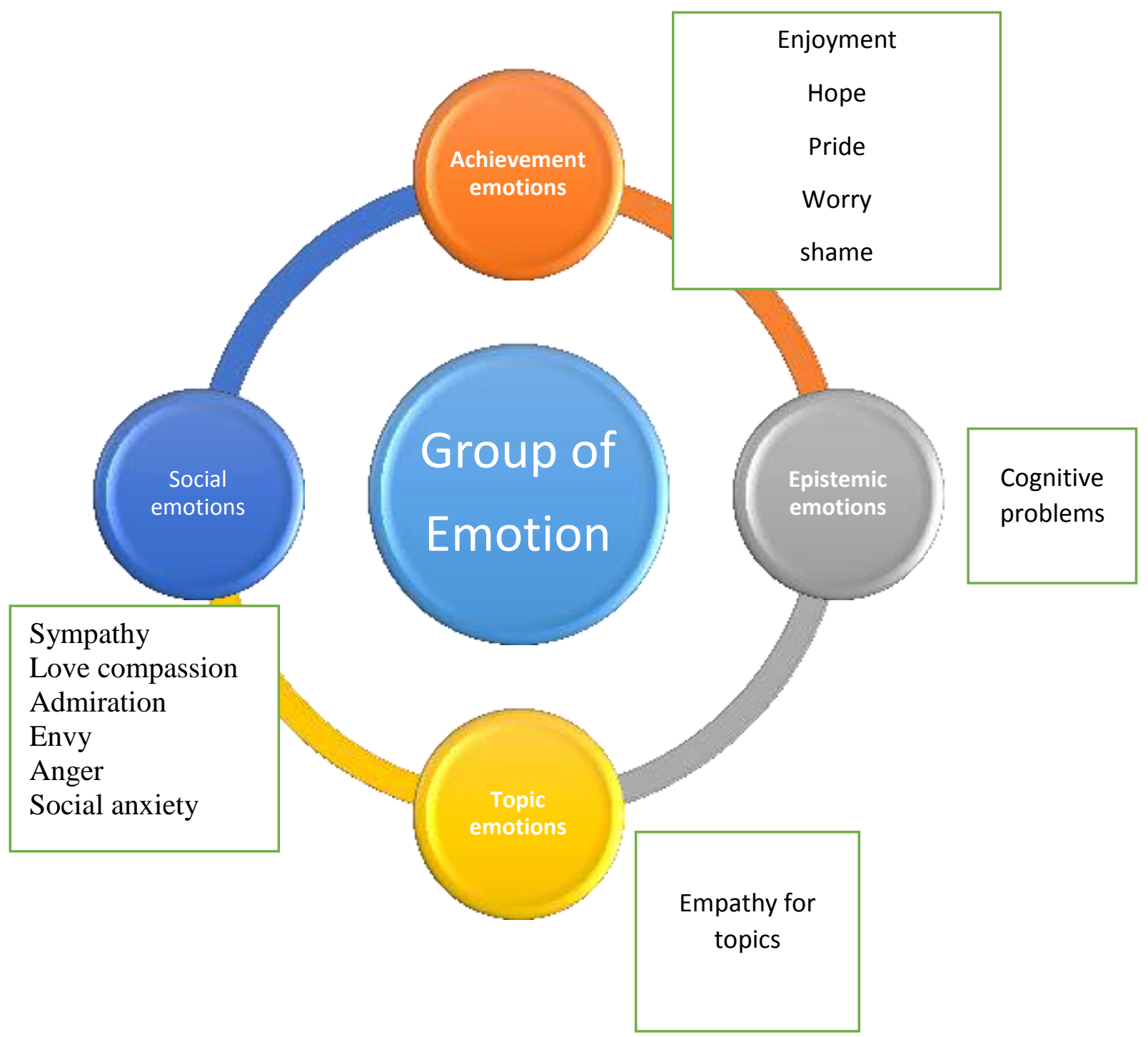

\section{LITERATURE BACKGROUND OF THE TOPIC}

How emotions manifest themselves in Japanese communication habits is a widely researched area in both linguistics and psychology. A number of studies are devoted to the lexical and grammatical features characterizing the terms of emotions in Japanese (Maeda, 1993; Ohso, 2001, Kiyomi, 2006), and the semantic structure of the expression of emotions is also closely related to this topic (Romney, Kimball, Rusch, 1997). In cross-cultural psychology, several authors describe a range of emotions more accessible to Japanese than others (Doi, 1981; Morschbach \& Tyler, 1986; Markus \& Kitayama, 1991; Kitayama, Mesquita, Karasawa, 2006). 


\section{EPRA International Journal of Research and Development (IJRD) \\ Volume: 6 | Issue: 12 | December 2021 \\ - Peer Reviewed Journal}

Other studies discuss Japanese cultural scripts that govern the order in which emotions are expressed and understood (Wierzbicka, 1996), emotional inference (Uchida et al., 2009), and the co-occurrence of positive and negative emotions in Japan (Miyamoto, Uchida, Ellsworth, 2010; Uchida and Kitayma, 2009). ${ }^{3}$

Recent research in word recognition has reported an interaction between the emotional quality of a word (characterized as positive, negative, or neutral) and frequency of occurrence (more or less common usage). These results were found in the response time to a lexical decision (Kuchinke et al. 2007; Scott et al. 2009), in electrophysiological stresses (Scott et al. 2009), as well as in the time of gaze fixation while reading a liquid (Scott et al., 2012). In particular, for words with low frequency (LF), behavioral responses to both positive and negative words were faster than responses to neutral words; for high frequency (HF) words, responses to positive words alone were faster than responses to negative or neutral words (which did not differ). The effects of early word frequency have been consistently demonstrated in eye movement and electrophysiology paradigms (see Hand et al., 2010) and are considered a reliable marker of lexical access (eg, Serenoand Rayner, 2003). Thus, the interaction of the emotional quality of a word with its frequency suggests the central role of emotion in the initial stages of word recognition. ${ }^{4}$

\section{METHOD}

Linguacultural analyze of Japanese and English emotive words comparatively in translation.

The linguacultural analyzing method is based on the chapter "Linguacultural analyze" of the book "Consecutive interpreting" by S.K.Fomin. ${ }^{5}$

\section{LINGUACULTURAL ANALYZE DEFINITION}

Linguacultural analysis of the text occupies a special place among research methods in cultural linguistics, since the text, in addition to creating its own space, completely captures the "world" of the culture in the language of which it was created. A careful study of the text helps to penetrate deeper into the culture of your country, the country of the target language, to reveal the meanings behind certain linguistic units, to understand the value attitudes and scenarios of a given culture, and as a result to form an idea of the picture of the world that exists in this culture.

The tasks of linguacultural analysis are:

1) the ability to extract information about the culture of the country from the text;

2) the ability to interpret the information received;

3) the ability to compare the value pictures of the world of different cultures.

The subject of linguacultural analysis is language units that "have acquired a symbolic, standard, figurativemetaphorical meaning in culture and which generalize the results of human consciousness proper - archetypal and prototypical, recorded in myths, legends, rituals, rituals, folklore and religious discourses, poetic and prosaic literary texts, phraseological units and metaphors, symbols and paremias (proverbs and sayings) ". [8] These are the units, in the meaning of which national-cultural specificity lies, which accumulate and transmit cultural experience from generation to generation. They include:

- Non-equivalent vocabulary and gaps;

- Mythologized linguistic units: archetypes and mythologemes;

- Standards, stereotypes, symbols;

- Paremia;

- Phraseologisms;

- Metaphors and images of language;

\footnotetext{
${ }^{3}$ Márton Szemerey. Linguistic Representation of Emotions in Japanese and Hungarian: Quantity and Abstractness. Acta Linguistica Asiatica, 2(1), 2012.

${ }^{4}$ Graham G. Scott at al. Emotion words and categories: evidence from lexical decision. Marta Olivetti Belardinelli and Springer-Verlag Berlin Heidelberg 2013.

${ }^{5}$ S.K.Fomin. Последовательный перевод. (Consecutive interpreting). М.: АСТ: Восток - Запад, 2006. 253p.
} 


\section{EPRA International Journal of Research and Development (IJRD)}

Volume: 6 | Issue: 12 | December 2021

- Peer Reviewed Journal

- Speech behavior;

- Speech etiquette;

- Key concepts of culture;

- Precedent phenomena. ${ }^{6}$

\section{RESULTS}

Linguacultural comparison of emotive words with the meaning of surprise in Japanese and English communication

\section{A) The semantics of ああ[aa] in Japanese}

In Japanese ああ[aa] has two meanings such as “in that way" and "surpirise emotion".

We try to clarify the differences special features of this exclamation with several examples.

・ あのように (in that way)

ああ高くつくとは思わなかった。[aa takaku to ha omowanakatta]

I didn't think it would cost that (so) much.

ああは言っても彼はやさしい人だ。[aa ha itte mo kare ha yasashii hito da]

In spite of his harsh way of speaking, he is kind at heart.

In order to understand clearly whether the meaning of ああ (in that way) is positive or negative we depend only on the context, situation or intonation (when it is verbal).

\section{- Meanings of surprise}

1. 感動、嘆いたりして - impression, a passionate expression of grief or sorrow.

ああ、うれしい。[aa, ureshii] Oh, I am so glad.

ああ、うらやましい。[aa, urayamashii] (Oh) How I envy you!

ああ、めんどうだ。[aa, mendou da] Oh, what a bother.

ああ、君だったのか。[aa, kimi datta no ka] Oh, it’s you.

In the Japanese sentences given above the emotive word [aa] is translated as "Oh" into English taking into consideration that English "Oh" means different emotions, such as surprise, disappointment and pleasure, often as a reaction to something someone has said.

ああ年をとったなあ。[aa toshi totta naa] Ah, I am getting old.

For this example, English exclamation "Ah" suits better as "ah" is used to express understanding, pleasure, pain, surprise or the fact that you have noticed something, so the last meaning "the fact that of noticing something" matches here.

ああ、それでわかった。 [aa, sore de wakatta] Aha, now I get it.

In English "Aha" is used when someone suddenly understands or finds something.

\section{2. 呼びかけ - Calling, Addressing}

${ }^{6}$ S.K.Fomin. Последовательный перевод. (Consecutive interpreting). М.: АСТ: Восток - Запад, 2006. - 253p. 
ああ、田中さん！ [aa, Tanaka san] Oh, hello Mr. Tanaka!

ああ、正樹君！ [aa, Masaki kun] Oh, hi there, Masaki!

In Japanese ああ can also mean as a calling somebody for greeting when people see suddenly somebody and say "Hello". (Oh, hello! / Oh, hi there)

ああ、その空は開けちゃだめだよ。[aa, sono mado ha akecha dame da yo]

Hey, you must not open that door.

In this example, speaker wants to draw listener's attention by saying [aa]. In translation we used "Hey" as it is used as a way of attracting someone's attention, sometimes in a way which is not very polite.

\section{3. 返事 - Responding}

もう帰ろうか。一ああ。[mou kaerou ka] - [aa] Shall we go home now? - Yeah.

Guests wish to go back. Host cannot hold them. It is impolite in Japanese culture. Even they surprise (maybe they haven't expected guest's decision or hosts just pretend as if they are surprised by saying [aa]) they follow guest's wish by responding "Yes".

気分が悪いのかい?ああ。[kibunga warui no kai] - [aa] -Are you feeling sick? - Uh-huh.

Uh-huh id a written representation of the sound that people sometimes make in order to agree with or show understanding of something that has just been said.

\section{B) English equivalents of ああ and their linguacultural specifications}

In English the equivalents of ああ [aa] can be “oh", "ah", "aha", "hi, there”, "hello", "hey".

Definitions of the exclamations mentioned above in English:

"Ah" - understanding, pleasure, pain, surprise or the fact that something have been noticed.

$\mathrm{Ah}$, I see.

Why has the train stopped? Ah, now we're off again.

Ah, Jessica, how wonderful to see you!

Ah, what a lovely baby!

"Oh" - surprise, disappointment and pleasure, often as a reaction to something someone has said, idea that one has just thought of, or something just has been remembered.

"I'm afraid I can't come to the party." " Oh, that's a shame."

Is that for me? Oh, you're so kind!

"I'm sorry I forgot to ring you." "Oh, don't worry.

Oh, I've just thought of a problem.

$\mathrm{Oh}$, and don't forget to lock the back door.

"Aha" is used when one suddenly understands or find somethings:

Aha, now I see what you mean!

Aha, that's where I put my keys!

"Hey" used as a way of attracting someone's attention 


\section{EPRA International Journal of Research and Development (IJRD)}

Volume: 6 | Issue: 12 | December 2021

Hey! What are you doing with my car?

Hey, are you guys coming to Angela's party?

\section{Linguacultural analyze:}

\begin{tabular}{|l|l|l|l|l|l|l|l|}
\hline Units & & & & & & \\
\end{tabular}

II. A) The semantics of あら [ara] in Japanese

あら [ara] is an emotive word used by females and means surprising as well as regretting.

驚きなどで - surprising

あらそうですか、どうぞご自由に。[ara sou desu ka, douzo go jibun ni]

"Oh, I see. Do whatever you wish, then."

ただいま。あら?お客様、見えてるの? [tadaima. Ara okyaku sama mieteru no] I'm back! Oh? Have we got a guest?

あらまあ、しばらくね。[ara maa shibaraku ne] My goodness, I have not seen you for ages!

あら、そうなの。[ara sou na no] Really? Is it so?

抗議・残念で -objection, regret 
彼女は他人のあらばかり探してる。 [kanojo ha tannin no ara bakari sagashite iru] She is always finding fault with others. ${ }^{7}$

あら、私はそうは思いませんよ。[ara, watashi ha sou ha omoimasen yo] Oh no, that's not what I think at all.

あら困ったは。[ara komatta ha] Oh dear! Heavens!

あら、大変。[ara, taihen] Uh-oh.

B) English equivalents of あら [ara] and their linguacultural specifications

In English the equivalents of ああ [aa] can be “oh”, “oh no”, “aw”, "really”, “Oh my goodness”, “Oh dear”, "Uh-oh".

Definitions of the exclamations mentioned above in English:

Oh, no! is an exclamation or expression of alarm, concern or resentment about a problem or error.

Oh, no! The rug is on fire!

Oh, no! Did I leave my keys in the car?

$\boldsymbol{A} \boldsymbol{w}$ is used to express mild protest, entreaty, or sympathy.

Aw, come on, Andy.

Expressing mild disappointment or self-deprecation.

Aw, it's a shame I can't make it.

Expressing pleasure, delight, or affection, especially in response to something regarded as sweet or endearing. Aww, the kitten is too cute!

Uh-oh is a written representation of the sound that people make when they discover that they have made a mistake or done something wrong.

Uh-oh, I think I just locked my keys in the car.

"Oh my goodness", "Oh dear"- emphasizing how surprised, angry, shocked, etc someone is.

My God, what a mess!

Oh my God, I've never seen anything like it!

\footnotetext{
${ }^{7}$ https://tangorin.com/definition/\%E3\%81\%82\%E3\%82\%89
} 


\begin{tabular}{|c|c|c|c|c|c|}
\hline Units & 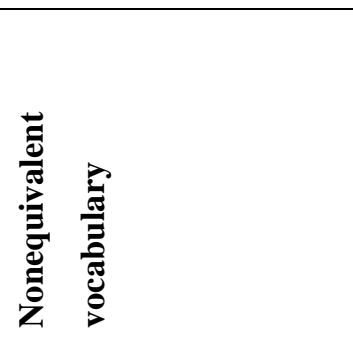 & 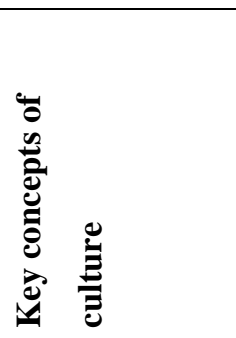 & ف류: & 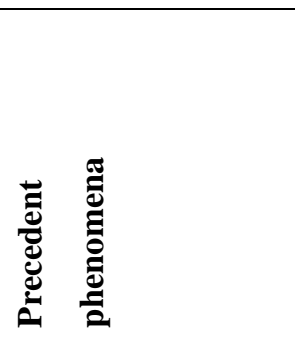 & 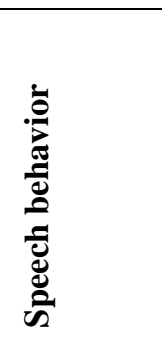 \\
\hline Japanese & $\begin{array}{cc}\text { ら } & \text { 彼 } \\
\text { ば } & \text { 女 } \\
\text { か } & \text { は } \\
\text { 梊 } & \text { 他 } \\
\text { 探 } & \text { の } \\
\text { て } & \text { あ }\end{array}$ & 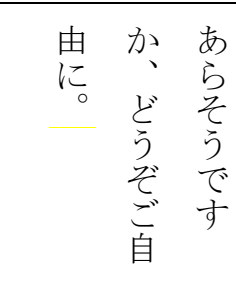 & $\begin{array}{l}\text { あ } \\
\vdots \\
\text { 困 } \\
\text { た } \\
\text { た } \\
\text { は }\end{array}$ & \begin{tabular}{ll} 
や & あ \\
$<$ & $ら$ \\
$ち$ & な \\
$p$ & \multicolumn{1}{c}{} \\
& $\tau$ \\
& め \\
& $\hbar$
\end{tabular} & $\begin{array}{cc}\text { は } & \text { あ } \\
\text { 思 } & ら \\
\text { ら } \\
\text { ま } & \text { 私 } \\
\text { せ } & \text { は } \\
\text { ん } & \text { そ } \\
\text { よ } & う\end{array}$ \\
\hline English & $\begin{array}{l}\text { She is always } \\
\text { finding fault with other } \\
\text { s what a mess! }\end{array}$ & $\begin{array}{l}\text { "Oh, I see. Do } \\
\text { whatever you } \\
\text { wish, then. }\end{array}$ & $\begin{array}{l}\text { Oh dear! } \\
\text { Heavens! }\end{array}$ & $\begin{array}{l}\text { My God, what a } \\
\text { mess! }\end{array}$ & $\begin{array}{l}\text { Oh no, } \\
\text { that's not } \\
\text { what I } \\
\text { think at } \\
\text { all. }\end{array}$ \\
\hline
\end{tabular}

There are other emotive words with the meaning of "surprise" in Japanese which can be researched deeply in further steps, such as おお: Oh! わあ: Wow! うそ ;嘘: No way!マジで: Seriously? (very casual) すごい: ほんとう

Great! ; 本当: Really?

げっ: Yuck, ack, gross! きゃあ: *Feminine shriek あら: Oh dear! (feminine) おっと: Oops がーん: *Sound effect for shock like "I'm shocked"

\section{CONCLUSION}

On linguacultural analyzing of the units comparatively, it was proved that there are nonequivalent words such as addressing ああ cannot be translated with one word, also あら can mean not only exclamation word but can replace the word "fault".

Speech etiquette analyze shows that responding to the guest (I am going! - Yes!) saying "Yes" in English politeness is not acceptable. Saying "Oh, Okay then" can be an appropriate option of the respond.

Key concept of culture shows that in Japanese people don't say exclamation with the meaning "Hey" and it would be better to use "You know" instead "Hey" (Hey, you must not open that window.)

Paroemia can be observed in both in English and Japanese. Japanese あら困った can be considered as paroemia but cannot be translated literally. In English the equvalent can be "Oh, dear!" "Oh, hell!"

The results of the research can contribute to clarify exact difference and linguacultural specifications of surprising emotive words in Japanese and English. 


\section{EPRA International Journal of Research and Development (IJRD)}

Volume: 6 | Issue: 12 | December 2021

- Peer Reviewed Journal

\section{REFERENCE}

1. Satoko Suzuki. Emotive Communciation in Japanese: An Introduction [Pragmatics \& Beyond New Series, 151] 2006. x, $234 \mathrm{pp}$

2. Pekrun, R. (2014). Emotions: Functions and effects on learning. In N. M. Seel(Ed.), Encyclopedia of the Sciences of Learning (pp. 1141-1146). NewYork: Springer

3. Márton Szemerey. Linguistic Representation of Emotions in Japanese and Hungarian: Quantity and Abstractness. Acta Linguistica Asiatica, 2(1), 2012.

4. Graham G. Scott at al. Emotion words and categories: evidence from lexical decision. Marta Olivetti Belardinelli and Springer-Verlag Berlin Heidelberg 2013.

5. S.K.Fomin. Последовательный перевод. (Consecutive interpreting). М.: ACT: Восток-3апад, 2006. - 253p.

6. Quora.com (Japanese emotive words)

7. Cambridge English dictionary 2006.

8. Ex-word dataplus 6. Electronical dictionary. 